\title{
Realizing Multicultural Education in History Learning: Strengthening Character to Increase National Competitiveness
}

\author{
Sariyatun, Abdul Rohman, Agus Mastrianto \\ Universitas Sebelas Maret \\ sariyatun@staff.uns.ac.id
}

\section{Article History}

accepted 1/09/2020

approved 4/10/2020

published $1 / 12 / 2020$

\begin{abstract}
Indonesia is a multicultural country that has various ethnicities, races, religions and cultures. However, the sense of mutual respect, respect and tolerance among Indonesians is now starting to diminish. This is of course a threat in itself for the Indonesian people, especially it will have an impact on the characteristics of the younger generation as the next generation who will determine the fate of the Indonesian people in the eyes of the world. Therefore, education is the main solution in dealing with these problems. Through multicultural education in history learning given in schools, it is hoped that a young generation of Indonesian character will emerge with character in order to increase the competitiveness of the Indonesian nation. This writing method uses a qualitative descriptive method. This writing aims to provide an idea or a new concept in the field of education, especially multicultural education in history learning in schools as an effort to strengthen the character of the nation. The conclusion of this writing is that through multicultural education in history learning, later we will have a young generation with character and uphold multicultural values. It is hoped that with this, the younger generation can be useful and participate in the efforts of the Indonesian people to face global competition in the international world.
\end{abstract}

Keywords: Multicultural education, history learning, character strengthening

\begin{abstract}
Abstrak
Indonesia merupakan negara multikultural yang mempunyai beranekaragam suku, ras, agama, dan budaya. Akan tetapi rasa saling menghargai, menghormati dan toleransi di antara masyarakat Indonesia sekarang ini mulai berkurang. Hal ini tentu saja menjadi ancaman tersendiri bagi bangsa Indonesia, utamanya akan berdampak pada karaktek yang akan dimiliki generasi muda sebagai generasi penerus yang akan menentukan nasib bangsa Indonesia di mata dunia. Oleh karena itu, pendidikan merupakan solusi utama dalam menghadapi permasalahan tersebut. Melalui pendidikan multikultural dalam pembelajaran sejarah yang diberikan di sekolah, diharapkan muncul generasi muda Indonesia yang berkarakter guna meningkatkan daya saing bangsa Indonesia. Metode penulisan ini menggunakan metode deskriptif kualitatif. Penulisan ini bertujuan untuk memberikan ide atau sebuah konsep baru dalam bidang pendidikan utamanya pendidikan multikultural dalam pembelajaran sejarah di sekolah sebagai upaya penguatan karakter bangsa. Kesimpulan dari penulisan ini melalui pendidikan multikultural dalam pembelajaran sejarah, nantinya kita mempunyai generasi muda yang berkarakter dan menjunjung tinggi nilai-nilai multikultural. Diharapkan dengan hal tersebut, generasi muda dapat bermanfaat dan berperan serta dalam upaya bangsa Indonesia menghadapi persaingan global di dunia Internasional.
\end{abstract}

Kata Kunci: Pendidikan multikultural, pembelajaran sejarah, penguatan karakter

\begin{tabular}{ll}
\hline Social, Humanities, and Education Studies (SHEs): Conference Series & p-ISSN 2620-9284 \\
https://jurnal.uns.ac.id/shes & e-ISSN 2620-9292
\end{tabular}

This work is licensed under a Creative Commons Attribution-ShareAlike 4.0 International License. 


\section{PENDAHULUAN}

Indonesia merupakan negara multikultural yang memiliki latar belakang suku, agama, ras dan budaya yang berbeda-beda. Keberagaman yang selama ini diijaga dengan baik mulai mengalami berbagai ancaman dan tantangan yang timbul oleh bermacammacam kondisi sehingga menyebabkan sering terjadi konflik di masyarakat. Di era global seperti sekarang ini, berbagai konflik yang dilatarbelakangi oleh perbedaan latar belakang sering terjadi. Hal tersebut ditandai dengan adanya aksi tawuran antar sekolah, sentimen keagamaan yang begitu kuat, diskriminasi, politik identitas bahkan perbuatan rasisme yang kebanyakan dilakukan oleh anak-anak usia sekolah kita.

$\mathrm{Hal}$ ini tentu menjadi ancaman yang serius bagi keberlangsungan generasi muda Indonesia, generasi muda yang seharusnya menjadi harapan dan kebanggan Indonesia di masa yang akan datang justru sering membuat konflik-konflik yang menyebabkan perpecahan. Faktor tersebut apabila tidak ada penanganan yang serius, dapat menjadi hambatan untuk kemajuan generasi muda utamanya dalam upaya bangsa Indonesia untuk meningkatkan kualitas daya saing bangsa. Meskipun jika kita berbicara mengenai daya saing bangsa, semua pasti tertuju pada bagaimana generasi muda kita bisa mempunyai kemampuan dalam menguasai bahkan berinovasi dalam bidang ilmu pengetahuan dan teknologi.

Selama ini kita lupa bahwa majunya sebuah generasi bangsa juga dipengaruhi bagaimana generasi mudanya mempunyai kualitas sumber daya manusia yang mumpuni. Hal ini dapat dilihat bagaimana kesiapan mental untuk menghadapi persaingan dengan dunia Internasional. Oleh karena itu, perhatian harus tertuju pada bagaimana kualitas dan karakter generasi muda Indonesia saat ini karena daya saing di era global akan kita temui berbagai macam generasi yang lebih banyak tentu dengan latar belakang budaya yang berbeda. Apabila permasalahan-permasalah yang selama ini menjadi hambatan utamanya dalam dunia pendidikan tidak segera diperbaiki, maka sudah tentu generasi muda Indonesia akan mengalami kegagalan dalam menghadapi persaingan global dan menjadikan generasi muda Indonesia tertinggal dengan generasi muda dari negara-negara lainnya.

Oleh karena itu, perlunya solusi sebuah ide gagasan atau konsep yang tepat untuk diterapkan kepada generasi muda melalui pendidikan. Pendidikan dianggap menjadi solusi utama dan satu-satunya dalam memperbaiki karakter generasi muda Indonesia. Melalui pendidikan, kita dapat menentukan bagaiman kualitas generasi muda dapat berperan dalam upaya meningkatkan daya saing bangsa Indonesia.

Pendidikan multikultural merupakan pendidikan yang sesuai dan solusi yang tepat

guna menghadapi berbagai permasalahan-permasalah yang terjadi. Pendidikan multikultural merupakan upaya kolektif untuk masyarakat majemuk. Pendidikan multikultural adalah pendidikan yang memperhatikan aspek keterampilan dan pengetahuan dasar bagi warga dunia, terutama sangat penting bagi generasi muda, menembus seluruh aspek dalam sistem pendidikan, mengembangkan sikap, pengetahuan dan keterampilan yang memungkinkan generasi muda mempunyai sikap keadilan sosial, toleransi, kasih sayang, saling menghormati dan menghargai perbedaan.

Hal ini juga sesuai dengan Undang-Undang Sistem Pendidikan Nasional Nomor 20 Tahun 2003, bahwa perubahan yang mendasar diwacanakan dalam undang-undang tersebut adalah demokratisasi dan desentralisasi pendidikan, peran serta masyarakat, tantangan globalisasi, kesetaraan dan keseimbangan, jalur pendidikan dan peserta didik. Bagaimana pemerintah mengupayakan peningkatan mutu sumberdaya manusia, mengejar 
ketertinggalan di berbagai aspek kehidupan dan menyesuaikan dengan perkembangan ilmu pengetahuan dan teknologi. Kebijakan-kebijakan tersebut harus didukung dengan pembelajaran yang dapat menanamkan dan mengembangkan nilai-nilai karakter pada diri generasi muda dalam hal ini anak usia sekolah. Pembelajaran sejarah merupakan sarana yang tepat untuk menanamkan berbagai nilai keberagaman dalam pendidikan multikultural.

Dalam pembelajaran sejarah, siswa dapat memaknai nilai-nilai humanisme melalui materi-materi dalam pembelajaran sejarah seperti kepahlawan tokoh Nasional atau daerah, organisasi-organisasi perjuangan dan tentu budaya-budaya yang selama ini ada dan berkembang di Indonesia. Hall ini juga dapat menjadi inovasi baru untuk guru dalam proses pembelajaran, karena selama ini guru hanya memberikan materi-materi yang tertulis dalam buku teks dan LKS. Sangat jarang guru memberikan dan mampu menanamkan nilai-nilai inti dari pendidikan multikultural, seperti demokrasi, humanisme, dan pluralisme atau menanamkan nilai-nilai keberagaman yang inklusif kepada siswa.

Melalui pendidikan multikultural dalam pembelajaran sejarah, diharapkan menjadi sebuah inovasi atau konsep baru untuk memperbarui proses pembelajaran yang terjadi di sekolah selama ini. Disisi lain, juga menyiapkan generasi muda yang berkompeten, berkarakter sesuai dengan perkembangan ilmu pengetahuan dan teknologi. Kedepannya, generasi muda Indoonesia dapat bermanfaat dan berperan penting dalam upaya bangsa Indonesia menghadapi persaingan global di dunia Internasional. Melalui pendidikan multikultural dalam pembelajaran sejarah, Indonesia dapat meningkatkan daya saing bangsa di era globalisasi dan dunia Internasional.

\section{METODE}

Dalam penelitian berjudul "Mewujudkan Pendidikan Multikultural dalam Pembelajaran Sejarah: Penguatan Karakter untuk meningkatkan Daya saing Bangsa", peneliti menggunakan metode penelitian deskriptif kualitatif. Penelitian deskriptif kualitatif ditujukan untuk mendeskripsikan dan menggambarkan fenomena-fenomena yang ada, baik bersifat alamiah maupun rekayasa manusia, yang lebih memperhatikan mengenai karakteristik, kualitas, keterkaitan antar kegiatan. Selain itu, penelitian deskriptif tidak memberikan perlakuan, manipulasi, ataupun perubahan pada variabel-variabel yang diteliti, melainkan menggambarkan suatu keadaan yang apa adanya. Satu-satunya perlakuan yang diberikan hanyalah penelitian itu sendiri yang dilakukan melalui salah satunya dengan tahapan observasi, dan dokumentasi (Sukmadinata, 2011:73).

\section{HASIL DAN PEMBAHASAN}

\section{Krisis Karakter Generasi Muda Indonesia}

Perkembangan pendidikan di Indonesia tidak dapat dilepaskan dari pengaruh globalisasi dunia, dimana ilmu pengetahuan dan teknologi berkembang pesat. Akan tetapi, perkembangan dalam dunia pendidikan ini memberikan sebuah permasalahan baru bagi pendidikan di Indonesia. salah satu permasalahan tersebut adalah krisis karakter sebagai sebuah bangsa yang di alami oleh generasi muda dalam hal ini merupakan anak-anak usia sekolah. Kementerian Pendidikan Nasional (Kemendiknas) mensinyalir bahwa sumber dari permasalahan kemerosotan moralitas bangsa ini disebabkan oleh terabaikannya pendidikan karakter (Suyadi, 2015:2) 
Berbagai permasalah karakter dalam dunia pendidikan Indonesia ditandandai dengan banyaknya kekerasan yang dilakukan oleh generasi muda kita. Aksi tawuran, siswa melawan guru, diskriminasi, seks bebas, intoleransi, tindakan rasis dan tindakan kriminal yang kesemuanya tidak mencerminkan sebagai generasi yang berkarakter dan berbudaya. Adapun faktor faktor yang melatarbelakangi berbagai tindakan kekerasan yang dilakukan oleh generasi muda kita, menurut Hufad (2003:54) dapat dirumuskan sebagai berikut:

1. Kesenjangan atau kecemburuan sosial yang tidak dapat diatasi dengan penggusuran atau menghilangkan orang lain

2. Wujud dari memperjuangkan demokrasi dan keadilan, walaupun antara demokrasi dan kekerasan adalah hal yang kontradiksi. Karena demokrasi adalah kebebasan dalam mencapai keadilan, sedangkan kekerasan justru menyebarkan ketakutan dan konflik yang tidak menentu yang lebih berasal pada terbatasnya paradigma individu

3. Kekerasan merupakan bagian dari skala besar reformasi dan pembangunan bangsa

4. Konflik agama, organisasi, kelompok, suku dan fanatisme yang berlebihan.

Data tahun 2018 dari Komisi Perlindungan Anak (KPAl), menyatakan bahwa sekitar 202 anak berhadapan dengan hukum akibat terlibat tawuran dalam rentang dua tahun terakhir dan sekitar 74 kasus anak dengan kepemilikian senjata tajam. Permasalah ini sudah tentu menjadi ancaman serius untuk kelangsungan pendidikan di Indonesia. Esensi pendidikan yang selama ini tercantum dalam pembukaan UUD 1945 alinea ke 4 yakni mencerdaskan kehidupan bangsa, yang diartikan bahwa pendidikan seharusnya tidak hanya dijadikan sebuah alat untuk menaikkan derajat ekonomi, akan tetapi juga harus dapat memanusiakan manusia dalam praktek nyatanya tidak terinternalisasi dengan baik, bahkan terkesan hanya sebagai sebuah konsep tanpa tindakan.

Permasalahan mengenai krisis karakter bangsa ini tidak hanya terletak pada generasi muda saja, akan tetapi sistem pembelajaran yang selama ini menjadi faktor utama yang menyebabkan berbagai permasalahan tersebut muncul. Salah satu yang menjadi kritikan tajam adalah proses pembelajaran yang berlangsung di sekolah, proses pembelajaran di sekolah selama ini hanya sekedar untuk mencapai target pencapaian kurikulum yang telah ditetapkan. Sehingga dalam prakteknya, siswa hanya mampu menerima informasi yang diberikan tanpa mendapatkan kesempatan untuk melakukan perenungan atau refleksi secara kritis. Materi yang disampaiakan hanya berupa konsepsikonsepsi pengetahuan dalam buku pelajaran dan keterampilan yang sudah ada tanpa ada pengkajian ulang. Hal ini tentu menjadikan proses pembelajaran di sekolah cenderung dijadikan formalitas oleh siswa, sehingga siswa tidak mendapatkan nilai-nilai karakter sebagai ouput apabila berada di luar lingkungan pendidikan formal.

Model pembelajaran seperti Pauolo Freire (2000) menyebut proses pembelajaran seperti diatas adalah konsep pendidikan gaya bank, konsep pendidikan yang dimaksud adalah sebagai berikut:

1. Guru mengajar, siswa diajar

2. Guru mengetahui segala sesuatu, siswa tidak mengetahui apapun

3. Guru berpikir, siswa dipikirkan

4. Guru bercerita, siswa dengan patuh mendengarkan cerita

5. Guru menentukan peraturan, siswa diatur 
6. Guru memilih dan memaksakan pilihannya, siswa selalu menhyetujui

7. Guru berbuat, siswa membayangkan dirinya berbuat melalui praktek gurunya

8. Guru memilih bahan dan materi pelajar, siswa selalu menyesuaikan diri dengan bahan dan materi yang diberikan

9. Guru mencampuradukkan kewenangan ilmu pengetahuan dan kewenangan jabatan, yang berdampak siswa tidak mempunyai kebebasan (Zein, 2017:22).

Berbagai permasalahan diatas apabila terus diabaikan tanpa sebuah solusi untuk mengatasinya, akan menjadi faktor utama yang dapat menghambat Indonesia dalam usahanya meningkatkan mutu sumber daya manusia dalam rangka menghadapi daya saing bangsa. Salah satu konsep atau solusi yang tepat dalam menghadapi krisis karakter generasi muda adalah melalui pendidikan multikultural. Pendidikan multikultural dirasa tepat karena sesuai dengan tujuan pendidikan Internasional yakni untuk meningkatkan kesadaran global dan saling pengertian Internasional (International Understanding) demi medujudkan kehidupan bersama dalam damai dan toleransi (Unesco, Apnieve, 2000). Mengacu pada hal ini, peningkatan daya saing bangsa yang dilakukan oleh Indonesia melalui sistem pendidikan tidak hanya memperhatikan aspek penguasaan terhadap perkembangan ilmu pengetahuan dan teknologi akan tetapi juga memperhatikan aspek karakter generasi muda Indonesia agar dapat sejajar dengan generasi muda bangsa lain.

\section{Konsep Pendidikan Multikultural}

Andersen dan Cusher (1994:320), bahwa pendidikan multikultural dapat diartikan sebagai pendidikan mengenai keberagaman kebudayaan. Pendidikan multikultural adalah strategi pendidikan yang diaplikasikan pada semua jenis mata pelajaran dengan cara menggunakan perbedaan-perbedaan kultural yang ada pada siswa seperti perbedaan etnis, agama, bahasa, gender, kelas sosial, ras, kemampuan, dan usia agar proses belajar menjadi efektif dan mudah. Pendidikan multikultural sekaligus dapat melatih dan membangun karakter siswa agar mampu bersikap demokratis, humanis, dan pluralis dalam lingkungan mereka (Yaqin, 2005:25).

Tujuan pendidikan multikultural adalah memberdayakan siswa untuk mengembangkan sifat-sifat yang humanis, seperti rasa hormat kepada orang yang berbeda budaya, memberi kesempatan untuk menjalin kerja sama dengan orang atau kelompok yang berbeda latar belakang secara langsung. Suparlan (2018:4) mengatakan bahwa tujuan pendidikan multikultural adalah untuk membantu siswa mengakui ketepatan dari pandangan-pandangan budaya yang beragam, membantu siswa dalam mengembangkan kebanggan terhadap warisan budaya, menyadarkan siswa bahwa konflik nilai sering menjadi faktor utama konflik antar kelompok masyarakat.

James Banks (1994) menjelaskan bahwa di dalam pendidikan multikultural terdapat beberapa dimensi yang saling berkaitan:

1. Content Integration, mengintegrasikan berbagai budaya dan kelompok untuk mengilustrasikan konsep mendasar, generalisasi dan teori dalam mata pelajaran atau disiplin ilmu

2. The Knowledge Construction Process, membawa siswa untuk memahami implikasi budaya ke dalam sebuah mata pelajaran (disiplin) 
3. An Equity Paedagogy, menyesuaikan metode pengajaran dengan cara belajar siswa dalam rangka memfasilitasi prestasi akademik siswa yang beragam baik dari segi ras, budaya atau sosial.

4. Prejudice Reduction, mengidentifikasi karakteristik siswa dan menentukan metode pengajaran mereka.

Pendidikan multikultural dapat di implementasikan pada tingkat deskriptif dan normatif, yang menggambarkan hal-hal dan permasalahan pendidikan yang berkaitan dengan masyarakat multikultural. Hal ini relevan dengan masalah-masalah yang dihadapi oleh bangsa Indonesia dalam rangka meningkatkan mutu daya saing bangsa, yakni permasalahan krisis karakter generasi muda dalam dunia pendidikan. Pendidikan multikultural mencakup pengertian tentang pertimbangan terhadap kebijakan-kebijakan dan strategi-strategi pendidikan dalam masyarakat multikultural.

Dalam konteks penjelasan tersebut, Mahfud (2013:180) mengatakan bahwa kurikulum pendidikan multikultural harus mencakup subyek-subyek seperti toleransi, tema tentang keberagaman etno-kultural dan agama, bahaya diskriminasi, penyelesaian konflik dan mediasi, HAM: demokrasi dan pluralitas, multikulturalisme, kemanusiaan universal dan subyek lainnya yang relevan dengan pendidikan multikultural.

Merancang pendidikan multikultural dalam tatanan masyarakat Indonesia yang beranekaragam tentu bukanlah hal yang mudah. Melihat kondisi ini, pendidikan multikultural harus diarahkan sebagai sarana untuk menciptakan masyarakat yang toleran, oleh karena itu pelru beberapa pendekatan yang digunakan dalam proses pendidikan multikultural. Terdapat empat pendekatan yang dapat digunakan dalam rangka mewujudkan pendidikan multikultural yakni sebagai berikut:

1. Tidak menyamakan pandangan pendidikan dengan persekolahan atau pendidikan multikultural dengan progam-progam yang dicanangkan sekolah formal

2. Menghindari pandangan yang menyamakan kebudayaan dengan kelompok etnis

3. Pengembangan kompetensi dalam suatu kebudayaan membutuhkan interaksi inisiatif dengan orang-orang yang mempunyai kompetensi, maka upaya untuk mendukung sekolah-sekolah yang terpisah secara etnis merupakan antitesis terhadap tujuan pendidikan multikultural.

4. Pendidikan multikultural meningkatkan kompetensi dalam beberapa kebudayaan. Kebudayaan mana yang akan diadopsi ditentukan oleh situasi dan kondisi secara proporsional.

\section{Pendidikan Multikultural dalam Pembelajaran Sejarah}

Dalam Visi Misi Pembangunan Nasional 2015-2019 yang dicanangkan oleh Kementerian Riset, Teknologi dan Pendidikan Tinggi tahun 2016, menyebutkan bahwa tujuannya adalah "Terwujudnya Indonesia yang berdaulat, Mandiri, dan Berkepribadian Berlandaskan Gotong Royong". Visi tersebut diwujudkan melalui tujuh misi pembangunan diantaranya adalah: 
SHEs: Conference Series 3 (2) (2020) 370- 379

1. Mewujudkan keamanan nasional yang mampu menjaga kedaulatan wilayah, menopang kemandirian ekonomi dengan mengamankan sumber daya maritim, dan mencerminkan kepribadian Indonesia sebagai negara kepulauan.

2. Mewujudkan masyarakat maju, berkeseimbangan, dan demokratis berlandaskan negara hukum.

3. Mewujudkan politik luar negeri bebas-aktif dan memperkuat jati diri sebagai negara maritim.

4. Mewujudkan kualitas hidup manusia Indonesia yang tinggi, maju, dan sejahtera.

5. Mewujudkan bangsa yang berdaya saing.

6. Mewujudkan Indonesia menjadi negara maritim yang mandiri, maju, kuat, dan berbasis kepentingan nasional.

7. Mewujudkan masyarakat yang berkepribadian dalam kebudayaan (Kemenristekdikti, 2016).

Melihat visi misi pembangunan nasional yang dicanangkan pemerintah memalui Kemenristekdikti tersebut, tentu dibutuhkan sebuah strategi untuk mewujudkan capaian Indonesia dalam rangka meningkatkan mutu daya saing bangsa. Hal terpenting yakni melalui inovasi sebuah gagasan atau konsep baru dalam pembelajaran di sekolah, karena dalam hal ini lingkungan pendidikan yang berperan penting dan pertama dalam meningkatkan aspek karakter generasi muda Indonesia.

Strategi pembelajaran sejarah dengan mengitegrasikan nilai-nilai pendidikan multikultural merupakan sebuah inovasi baru dalam dunia pendidikan. Hal ini tentu relevan, selain untuk memperkuat karakter siswa juga bertujuan untuk mewujudkan visi misi pembangunan nasional dalam rangka meningkatkan mutu daya saing bangsa. Widja (1989:27) mengatakan bahwa dalam pembelajaran sejarah sendiri memiliki tujuan-tujuan dalam proses pembelajarannya, tujuan tersebut meliputi:

1. Aspek Pengetahuan

a. Menguasai pengetahuan tentang aktivitas manusia di masa lampau

b. Menguasai pengetahuan mengenai fakta khusus dari peristiwa masa lampau.

c. Menguasai pengetahuan mengenai unsur umum yang tampak dari sejumlah peristiwa masa lampau

d. Menumbuhkan pengertian tentang makna serta hubungan peristiwa masa lampau dengan masa yang akan datang.

2. Aspek Pengembangan Sikap

a. Menumbuhkan kesadaran sejarah bagi peserta didik terutama agar mampu berpikir dan bertindak.

b. Menumbuhkan sikap menghargai peristiwa untuk kehidupan suatu bangsa.

c. Menumbuhkan sikap menghargai berbagai aspek kehidupan masa sekarang dari kehidupan masa lampau.

d. Menumbuhkan kesadaran mengenai perubahan yang sudah terjadi pada suatu bangsa yang diharapkan menuju kehidupan yang lebih baik dimasa yang akan datang.

3. Aspek Keterampilan 
SHEs: Conference Series 3 (2) (2020) 370- 379

a. Pembelajaran sejarah menekankan pada pengembangan kemampuan dasar peserta didik berupa keterampilan mencari jejak sejarah, keterampilan merangkai fakta sejarah.

b. Keterampilan menelaah secara elementer buku-buku sejarah, terutama yang berkaitan dengan sejarah bangsanya.

c. Keterampilan mengajukan pertanyaan yang produktif mengenai masalah sejarah.

d. Kemampuan bercerita mengenai peristiwa sejarah.

Pembelajaran sejarah juga dapat menjadi sarana yang baik untuk pendidikan nilai dalam pendidikan multikultural dalam hal ini termasuk bertujuan memperkuat karakter siswa dalam meningkatkan mutu daya saing bangsa. Kita ketahui bersama bahwa dalam pembelajaran sejarah sudah termuat nilai-nilai moral yang memiliki karakteristik berbedabeda. Karena setiap peristiwa sejarah sendiri merupakan fenomena empiris yang didalamnya memiliki nilai-nilai moral dan nilai-nilai kehidupan yang dapat diimplementasikan siswa di lingkungan keluarga, sekolah dan masyarakat. Pembelajaran Sejarah dirancang untuk membekali peserta didik dengan keterampilan dan cara berfikir sejarah, membentuk kesadaran menumbuh kembangkan nilai-nilai kebangsaan, mengembangkan inspirasi, dan mengaitkan peristiwa lokal dengan peristiwa nasional dalam satu rangkaian Sejarah Indonesia.

Dalam mewujudkan pendidikan multikultural dalam pembelajaran sejarah digunakan strategi pembelajaran analisis nilai, penggunaan strategi diarahkan pada tujuan agar siswa aktif selama proses pembelajaran melalui pengkajian nilai-nilai tertentu yang pada gilirannya, siswa memiliki komitmen terhadap nilai tersebut. Manfaatnya adalah: mengarahkan dan melatih penalaran siswa dalam menentukan pilihan terhadap suatu nilai tertentu sehingga pilihannya benar-benar dilandasi keyakinan yang kokoh, menunjukkan dan menyadarkan kepada siswa akan adanya suatu nilai yang luhur, melatih siswa agar dalam berperilaku selalu berpedoman kepada suatu nilai tertentu yang dianggap luhur.

Dalam pembelajaran sejarah, mengacu pada Kurikulum 2013 terdapat rumusan Kompetensi Dasar (KD) dikembangkan dengan memperhatikan karakteristik siswa, kemampuan awal, serta ciri dari mata pelajaran. Pendidikan multikultural dengan menggunakan strategi pembelajaran analisis nilai dapat di integrasikan dalam tema materi pembelajaran sejarah kelas sepuluh, pemilihan kelas sepuluh sebagai subyek penulisan tidak terlepad dari pentingnya pendidikan multikultural apabila diterapkan dan diberikan kepada siswa ketika baru memasuki tingkat sekolah menengah atas, kompetensi dasarnya adalah sebagai berikut:

Kelas X (SMA) :

1. Kompetensi Dasar (KD) 3.4. Menganalisis berbagai teori tentang proses masuknya agama dan kebudayaan Hindu dan Buddha ke Indonesia.

2. Kompetensi Dasar (KD) 3.5 Menganalisis perkembangan kehidupan masyarakat, pemerintahan, dan budaya pada masa kerajaan-kerajaan Hindu dan Buddha di Indonesia serta menunjukkan contoh bukti-bukti yang masih berlaku pada kehidupan masyarakat Indonesia masa kini.

3. Kompetensi Dasar (KD) 3.7 Menganalisis berbagai teori tentang proses masuknya agama dan kebudayaan Islam ke Indonesia 
SHEs: Conference Series 3 (2) (2020) 370- 379

4. Kompetensi Dasar (KD) 3.8 Menganalisis perkembangan kehidupan masyarakat, pemerintahan dan budaya pada masa kerajaan-kerajaan Islam di Indonesia serta menunjukkan contoh bukti-bukti yang masih berlaku pada kehidupan masyarakat Indonesia masa kini.

Dengan konsep pendidikan multikultural dalam pembelajaran sejarah, siswa mampu menjadi generasi muda yang memegang nilai-nilai budayanya sendiri sebagai penguatan karakter dalam rangka meningkatkan mutu daya bangsa Indonesia di era globalisasi. Generasi muda tidak hanya mempunyai kemampuan dalam ilmu pengetahuan dan teknologi, akan tetapi juga memiliki sikap spiritual yang kuat, cinta kasih sesama, toleransi, jujur, bertanggung jawab, dan lebih utama dapat menjadi generasi muda yang membanggakan Indonesia.

\section{SIMPULAN}

Pendidikan multikultural adalah strategi pendidikan yang diaplikasikan pada semua jenis mata pelajaran dengan cara menggunakan perbedaan-perbedaan kultural yang ada pada siswa seperti perbedaan etnis, agama, bahasa, gender, kelas sosial, ras, kemampuan, dan usia agar proses belajar menjadi efektif dan mudah. Pembelajaran Sejarah dirancang untuk membekali peserta didik dengan keterampilan dan cara berfikir sejarah, membentuk kesadaran menumbuh kembangkan nilai-nilai kebangsaan, mengembangkan inspirasi, dan mengaitkan peristiwa lokal dengan peristiwa nasional dalam satu rangkaian Sejarah Indonesia. Strategi pembelajaran analisis nilai merupakan model penyajian bahan pembelajaran yang bertolak dan berorientasi pada proses pengkajian nilai yang terkait dengan obyek atau kualitas obyek.

\section{DAFTAR PUSTAKA}

Freire, P. (2000). Pendidikan Pembebasan. Jakarta: LP3S

Hakim, S \& Untari, S. (2018). Pendidikan Multikultural: Strategi Inovatif Pembelajaran dalam Pluralitas Masyarakat Indonesia. Malang: Madani Media.

Hufad, A. (2003). Perilaku Kekerasan: Analisis Menurut Sistem Budaya dan Implikasi Edukatif. Jurnal Universitas Pendidikan Indonesia, No. 2/XXII/2003.

Istiarsono, Z. (2017). Tantangan Pendidikan dalam Era Globalisasi: Kajian Teoritik. Jurnal Intelegensia, Volume 1, Nomor 2 Tahun 2017. HIm 19-24.

Komisi Perlindungan Anak Indonesia (KPAI). 202 anak tawuran dalam dua tahun. 8 September 2018. Diakses pada tanggal 1 mei 2019. 11.00 WIB.

Mahfud, C. (2013). Pendidikan Multikultural. Yogyakarta: Pustaka Pelajar.

Mohamad Nasir (Ristekdikti). (2016). Pendidikan Tinggi: Membangun Indonesia Unggul dan Berdaya Saing. Yogyakarta, 04 Desember 2016. 
SHEs: Conference Series 3 (2) (2020) 370- 379

Suyadi. (2015). Strategi Pembelajaran Pendidikan Karakter. Bandung: Remaja Rosda Karya.

Sukmadinata, N. (2011). Metode Penelitian Pendidikan. Bandung: PT Remaja Rosdakarya.

Suryana, Y \& Rusdiana. (2015). Pendidikan Multikultural, Suatu Upaya penguatan Jati Diri bangsa: Konsep-Prinsip-Implementasi. Bandung: Pustaka Setia 